\title{
The performance of up-draft gasifier with various of air flow rate in gasification palm starch waste
}

\author{
Herman Saputro ${ }^{1, *}$, Imam Muttaqin ${ }^{1}$, Supriyadi Supriyadi ${ }^{1}$, Vani Fadlullah $^{1}$, Laila Fitriana ${ }^{2}$, Tutuko Firdani ${ }^{1}$, Riyadi \\ Muslim $^{1}$, Khaniffudin Khaniffudin ${ }^{1}$, Sri Lasmini ${ }^{1}$, Valiant L P Sutrisno ${ }^{1}$, Danar $S$ Wijayanto ${ }^{1}$, and Fudhail $A$ Munir $^{3}$ \\ ${ }^{1}$ Department of Mechanical Engineering Education, Universitas Sebelas Maret, Jl. Ahmad Yani No. 200, Pabelan, Surakarta, Indonesia
${ }^{2}$ Department of Mathematic Education, Universitas Sebelas Maret, Jl. Ir. Sutami 36A, Surakarta, Indonesia
${ }^{3}$ Faculty of Mechanical Engineering, Universiti Teknikal Malaysia Melaka, 76100 Hang Tuah Jaya, Durian Tunggal Melaka, Malaysia
}

Abstract. Conversion of palm starch waste biomass into energy sources through gasification process could be done to meet the energy requirement in palm noodle industry. This research used the Refuse Derived Fuel (RDF-5) based on the palm Starch waste. This is due to the how to overcome the solid waste around the home industry of noodle in Jawa Tengah. This study was conducted to determine the performance of up-draft gasifier with variations of air flow rate, i.e., $72 \mathrm{lpm}, 95 \mathrm{lpm}$, and $123 \mathrm{lpm}$. The results showed that the variation of air flow rate has affected to the gasification product. The optimum LHV value occurred at $122 \mathrm{l} / \mathrm{m}$ air flow rate, where the LHV value increased with the increase of air flow rate, but after passing $122 \mathrm{l} / \mathrm{m}$, the LHV value was continually decreasing.

\section{Introduction}

Home industry plays an essential role in the economic improvement in Indonesia. In Bendo village, Klaten city there is 137 home industry of palm processing. Home industry in Klaten city processed the palm tree to produce the palm flour, subsequently processed into noodles. However, the processing of palm trees also produces waste that pollutes the environment. Every home industry produces $600-700 \mathrm{Kg} /$ day of palm starch waste (solid waste). The waste is currently untapped and well-processed, making it a problem for the environment. The palm starch waste has the potential as biomass for energy generation.

The method to convert biomass into energy, there are many approaches such as direct combustion, gasification, liquefaction and anaerobic digestion [1]. Palm starch waste can be converted into renewable energy through the several ways; one of them is a gasification process [2], [3] and [4]. After 1946 (world war 2) the use of gasification technology decreased due to less efficient and fossil fuels cheaper than the cost of gasification [5]. However, nowadays the use of gasification technology evolved again, due to the waste problems and the presence of biomass [6]. Gasification is the process of converting solid fuels into flammable gas through a combustion process with limited air supply within the reactor into a gas, called syngas and some secondary liquid and solid products.

The process of biomass gasification occurs in a reactor called a gasifier. Gasifiers can be either fixed bed or fluidized bed. Gasification reactor is divided into four main sections with different temperature characteristics,: Drying $\quad\left(25^{\circ} \mathrm{C}-150^{\circ} \mathrm{C}\right)$, pyrolysis $\left(150^{\circ} \mathrm{C}-600^{\circ} \mathrm{C}\right)$, Oxidation $\left(800^{\circ} \mathrm{C}-1400^{\circ} \mathrm{C}\right)$ and Reduction $\left(600^{\circ} \mathrm{C}-\right.$ $\left.800^{\circ} \mathrm{C}\right)$. The gas produced by the gasification process is called syngas $\left(\mathrm{CO}, \mathrm{CH}_{4}, \mathrm{H}_{2}\right)$ [1]. In this study intends to optimize the quality of the fixed bed gasifier, updraft gasifier types for biomass waste palm starch.

The research to optimize updraft gasifier has been conducted either experiment [4], [7], [8] or simulation [9], [10]. Saputro et al. conducted gasification efficiency studies using CFD simulations to investigate the purification of gasification systems. The results showed that the addition of counter cone to the separator cyclone was able to capture the char and soot particles and separate the syngas with the particles to increase the efficiency of the syngas distribution. The best counter cone corner is $120^{\circ}$ which is capable of capturing particles of a size below $1 \mu \mathrm{m}$.

Wang et al. [11] conducted a study to improve the syngas yield and quality through the steam and indirect or external heat supply. They also reported that by using a gasifier updraft integrated with a gas reformer to drive the engine with gas fuel. The results showed that the heat value produced $3.9 \mathrm{MJ} / \mathrm{m}^{3}$ with the gasification efficiency of $60 \%$. Saravanakumar et al. [12] conducted gasification research using a bottom lift updraft gasifier with wood fuel. The results showed that the rate of fuel use between $9-10 \mathrm{~kg} /$ hour produces an efficiency of $73 \%$ with an average fire temperature of $750^{\circ} \mathrm{C}$. Mustafa [13] in his research explains that the inner flow velocity affects the increase in temperature, humidity, and the addition of heat to the air.

\footnotetext{
* Corresponding author: hermansaputro@staff.uns.ac.id
} 
This research used the Refuse Derived Fuel (RDF-5) based on the palm starch waste. In this study, observations have been made using RDF of palm starch waste by providing varying airflow rates. This research used cyclone separator simulation result from Saputro et al. i.e., [10] counter cone with $120^{\circ}$, due to the optimization of syngas quality.

\section{Research method}

The study was conducted using updraft type gasifier. The dimensions of the gasification reactor are shown in Fig. 1. The research was held at the Laboratory of Energy Conversion and Combustion (ECCL), Department of Mechanical Engineering Education, Universitas Sebelas Maret.

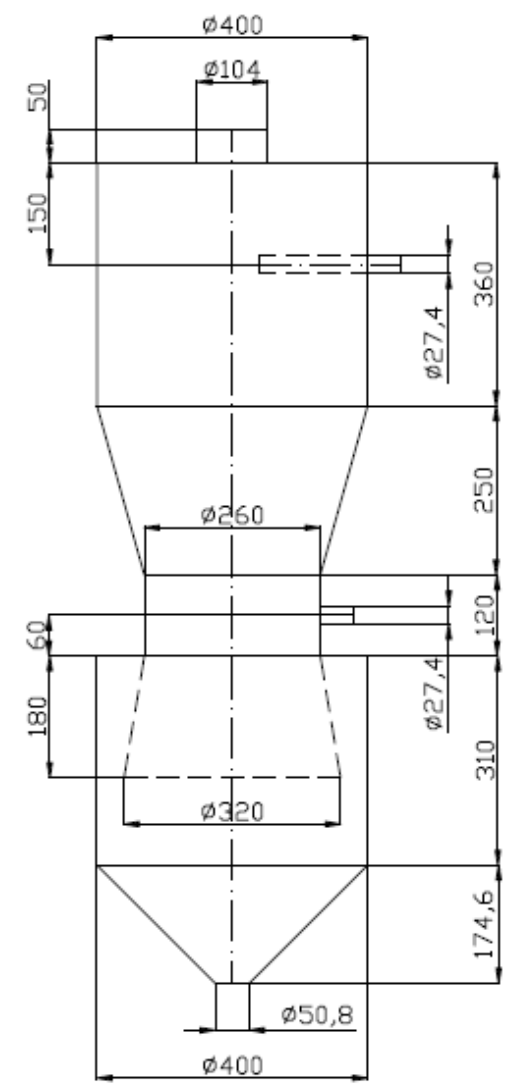

Fig. 1. Gasification Reactor type Up-draft.

The proximate and ultimate analysis was conducted on RDF of palm starch waste before the biomass combustion on the gasifier. All RDF of palm starch waste was tested using ASTM standards such as moisture content in RDF tested using ASTM D-3173 standard, RDF volatile tested using ASTM standard E897-88 and ash content tested using ASTM E-830-87.

Measurement of moisture content is done by placing the sample on crucible and heated to a minimum of free vacuum airspace oven for 2 hours. Then weighing measurements of RDF sample to know the weight before and after heated. The analysis of volatile content was carried out by heating the RDF sample on the Volatile
Matter Furnace at $900^{\circ} \mathrm{C}$ for 7 minutes, then comparing the weight before and after the heating. The ash content test was almost the same as the volatile content test. The sample was heated at Muffle Furnace at $500^{\circ} \mathrm{C}$ for 30 minutes. Then the temperature is again raised up to $815^{\circ} \mathrm{C}$ with a holding time of 1 hour. After several tests above, measurements of Carbon Fixed Percentage conducted by using formula (Eq.1).

$$
\begin{gathered}
\% C=100 \%-(\% \text { moisture content }+ \\
\% \text { ash content }+\% \text { volatile content })
\end{gathered}
$$

The ultimate analysis conducted at TekMIRA Bandung Testing Laboratory and the proximate study undertaken at central laboratory of Universitas Sebelas Maret. Table 1 and 2 was shown the results of proximate analysis and Ultimate analysis.

Table 1. Proximate Analyses

\begin{tabular}{|l|c|}
\hline \multicolumn{2}{|c|}{ Analisis Proximate (\% Weight) } \\
\hline Moisture Air Dried & 1337 \\
\hline Ash & 3.27 \\
\hline Volatile Matter & 72.27 \\
\hline Carbon Fixed & 11.09 \\
\hline
\end{tabular}

Table 2. Ultimate analysis of RDF Palm Waste

\begin{tabular}{|l|c|}
\hline \multicolumn{2}{|c|}{ Analisis Ultimate (\% Weight) } \\
\hline Carbon & 38.74 \\
\hline Oksigen & 51.25 \\
\hline Hydrogen & 6.41 \\
\hline Nitrogen & 0.26 \\
\hline Sulfur & 0.07 \\
\hline
\end{tabular}

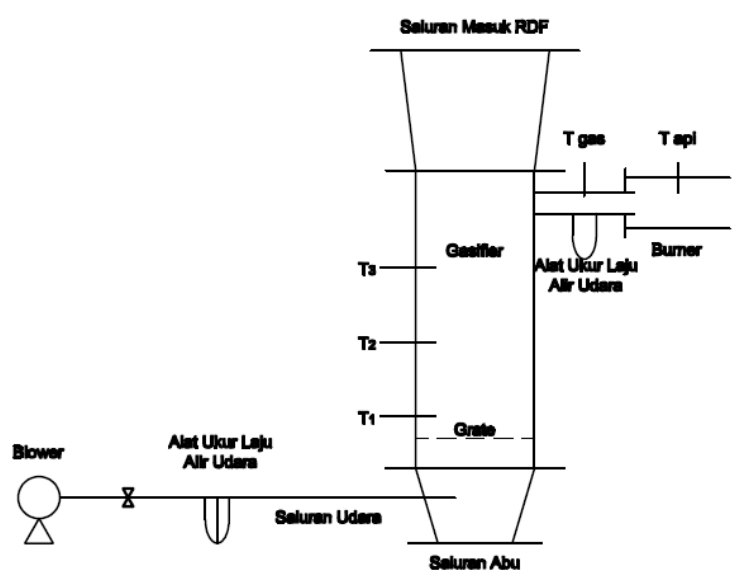

Fig. 2. Schema of Gasification.

RDF biomass of palm starch waste which has been analyzed by proximate and ultimate is burned in gasification reactor with variation in combustion air flow rate. In this experiment used blowers with a maximum rotation of $2200 \mathrm{rpm}$ and a maximum airflow capacity of $1050 \mathrm{lpm}$. The variation of the air flow used was 70 $\mathrm{lpm}, 95 \mathrm{lpm}$, and $123 \mathrm{lpm}$. The flow rate of air entering and coming out of the reactor was measured using a 
manometer. Data collection was performed in three stages, and each stage has 3 hours of testing pause. Each pause data retrieval $2 \mathrm{~kg}$ biomass RDF added to the reactor. In the reactor are installed $\mathrm{K}$ type thermocouple as much as six pieces, each placed in the drying zone, pyrolysis zone, oxidation zone, reduction zone, the area near the burner and outlet reactor (as shown in Fig. 2).

\section{Result and Discussion}

The experimental results have shown that RDF biomass of palm starch wastes able to produce syngas through gasification process at the type of updraft gasification reactor. Figure 2 shows that the syngas generated from the gasification process of palm waste. The figure shows a steady flame from the burning of syngas. Gasification performance shows that each stage of data retrieval (every 3 hours) is capable of producing a stable flame, although there is a difference in each data retrieval. Performance gasification was seen in Table 3.

Table 3. Gasification performance.

\begin{tabular}{|c|c|c|c|}
\hline \multirow{2}{*}{ Parameters } & \multicolumn{3}{|c|}{ Data } \\
\hline & Stage 1 & Stage 2 & Stage 3 \\
\hline $\begin{array}{l}\text { Water } \\
\text { content of } \\
\text { RDF }\end{array}$ & $13.37 \%$ & $13.37 \%$ & $13.37 \%$ \\
\hline $\begin{array}{l}\text { Dimension } \\
\text { of RDF }\end{array}$ & $\begin{array}{c}\text { Radius: } 2 \\
\mathrm{~cm} \text {, length: } \\
6 \mathrm{~cm}\end{array}$ & $\begin{array}{c}\text { Radius: } 2 \\
\mathrm{~cm} \text {, length: } \\
6 \mathrm{~cm}\end{array}$ & $\begin{array}{c}\text { Radius: } 2 \\
\mathrm{~cm} \text {, length: } \\
6 \mathrm{~cm}\end{array}$ \\
\hline $\begin{array}{l}\text { Input } \\
\text { method of } \\
\text { Fuel }\end{array}$ & $\begin{array}{c}\text { Batch, } 2 \\
\mathrm{~kg} / \mathrm{h}\end{array}$ & $\begin{array}{c}\text { Batch, } 2 \\
\mathrm{~kg} / \mathrm{h}\end{array}$ & $\begin{array}{c}\text { Batch, } 2 \\
\mathrm{~kg} / \mathrm{h}\end{array}$ \\
\hline $\begin{array}{l}\text { Air Flow } \\
\text { Rate }\end{array}$ & $72 \mathrm{lpm}$ & $92 \mathrm{lpm}$ & $123 \mathrm{lpm}$ \\
\hline $\begin{array}{l}\text { Gas } \\
\text { Flowrate }\end{array}$ & $90 \mathrm{lpm}$ & $127 \mathrm{lpm}$ & $140 \mathrm{lpm}$ \\
\hline $\begin{array}{l}\text { Temperature } \\
\text { of Drying } \\
\text { phase (T1 } \\
\left.{ }^{0} \mathrm{C}\right)\end{array}$ & 142 & 180.4 & 199.3 \\
\hline $\begin{array}{l}\text { Temperature } \\
\text { of Pyrolysis } \\
\text { phase (T2 } \\
{ }^{0} \mathrm{C} \text { ) }\end{array}$ & 342.3 & 412 & 453 \\
\hline $\begin{array}{l}\text { Temperature } \\
\text { of Oxidation } \\
\text { phase (T3 } \\
{ }^{0} \mathrm{C} \text { ) }\end{array}$ & 760.3 & 792 & 821.7 \\
\hline $\begin{array}{l}\text { Temperature } \\
\text { of } \\
\text { Reduction } \\
\text { phase (T4 } \\
\text { phe }\end{array}$ & 560.5 & 594.4 & 622 \\
\hline $\begin{array}{l}\text { Temperature } \\
\text { of Syngas } \\
\left(\mathrm{T} 5{ }^{0} \mathrm{C}\right)\end{array}$ & 173.7 & 192.3 & 223.4 \\
\hline $\begin{array}{l}\text { Temperature } \\
\text { of Flame } \\
\left(\mathrm{T} 6{ }^{\circ} \mathrm{C}\right)\end{array}$ & 592.6 & 602.5 & 628 \\
\hline
\end{tabular}
performance of palm starch wastes. These results provide information about the relationship between air flow rate and temperature reactor. Figure 4 shows the effect of the air flow rate in the reactor to the temperature.

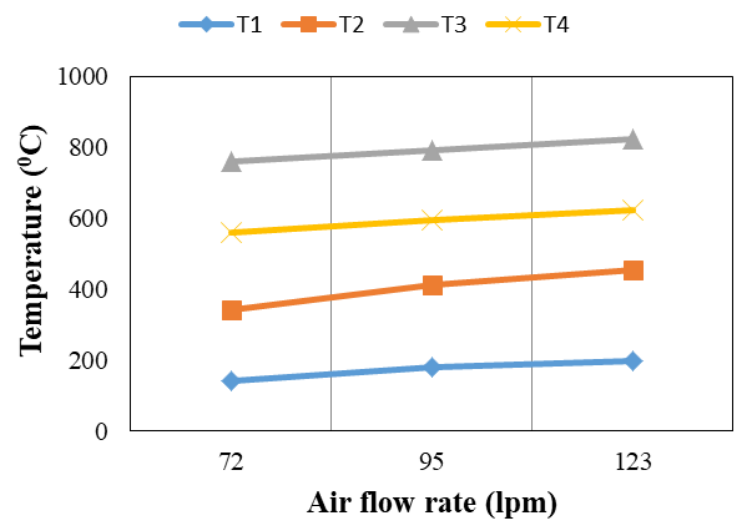

Fig. 4. The relation of air flow rate and the reactor temperature.

Measurement of reactor temperature was carried out at 4 phases which are phases in the gasification process, i.e., drying phase (T1), pyrolysis phase (T2), oxidation phase (T3) and reduction phase (T4). The measurement results show that the airflow rate affects the temperature values in each phase of the reactor. In other words, if the airflow rate increases, the temperature at each phase in the reactor also increases. In the air flow rate $=123 \mathrm{lpm}$ produce reactor temperature higher than the air flow rate $72 \mathrm{lpm}$ and $95 \mathrm{lpm}$. These results indicate that the airflow rate affects the chemical reaction of biomass in the phases of the gasification process. High airflow rate causes increased penetration of incoming air volume in the reactor so that more oxidized biomass. The heat at the reactor increases with the oxidation process. That heat supports the equilibrium reaction that occurs in the drying and pyrolysis areas. 


\subsection{The Effect of Air Flow Rate Burning to Gas Flow Rate}

The increase of combustion air flow rate is in line with the syngas flow rate. This is due to the high air supply causes the amount of oxygen involved in the combustion reaction to increase as well. Furthermore, combustion reactions produce $\mathrm{CO} 2$ and carbon charcoal formed also more. As a result there is an increase in the number of reactions in the reduction zone, the reaction between $\mathrm{CO} 2 \neg$ and $\mathrm{H} 2 \mathrm{O}$ forms $\mathrm{CO}, \mathrm{H} 2$, and $\mathrm{CH} 4$ gas which then comes out as the output of the gasification process.

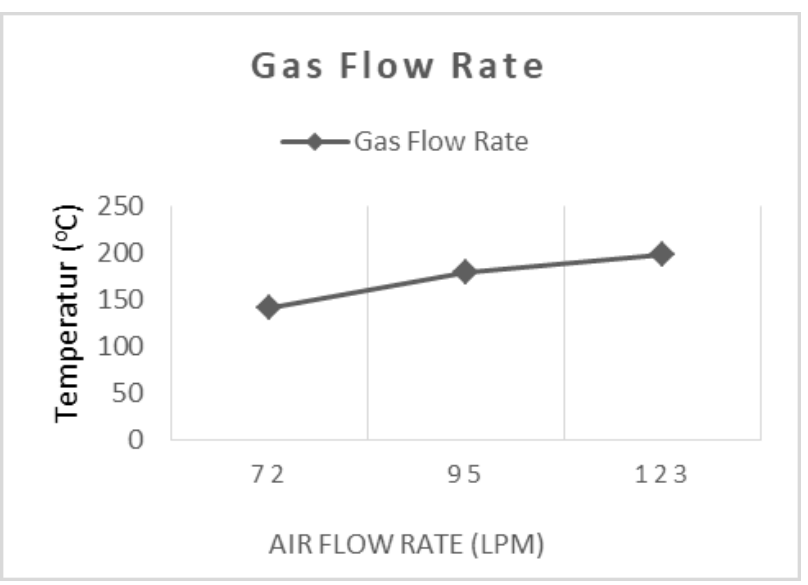

Fig. 5. Air Flow Rate Vs Gas Flow Rate.

\subsection{The Effect of Air Flow Rate Burning to Syngas Temperature}

The output gas from the gasification process is composed of $\mathrm{CO}, \mathrm{H} 2$, and $\mathrm{CH} 4$. Overall the components are generated from the combustion process that occurs in the reactor. When the temperature in the reactor increases, the output gas from the reactor also increases.

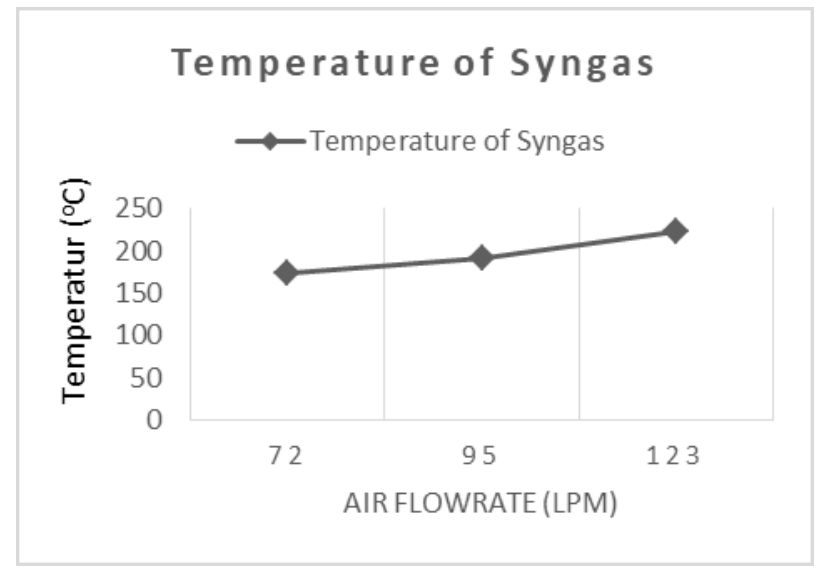

Fig 6. Air Flow rate Vs Temperatur of Syngas.

\subsection{The Effect of Air Flow Rate Burning to Fire Temperature}

The increase in the rate of combustion air is in line with the increase of fire temperature. An increase in the amount of combustible gas produced from an increase in combustion air flow rate necessarily causes the amount of heat released during the combustion process also increases. Visually, this can be seen by the change of fire color on the burner from orange to dark red.

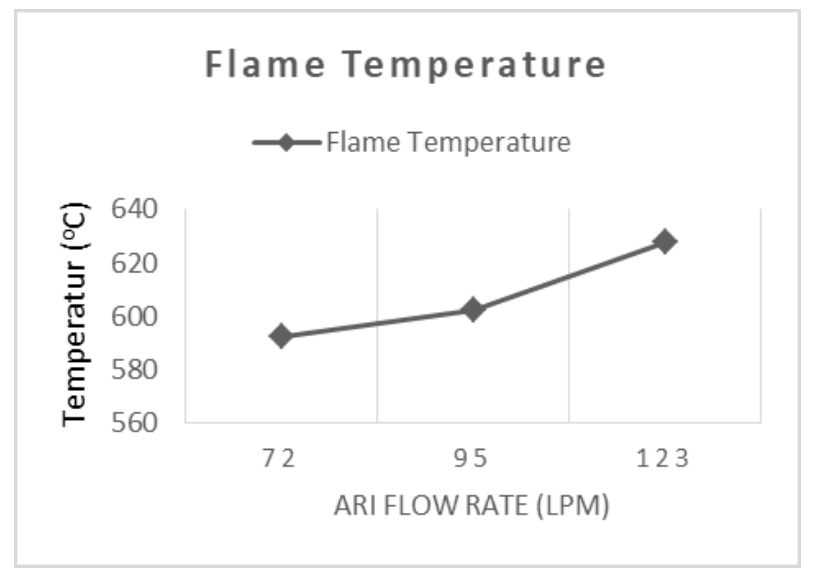

Fig 7. Air Flow rate Vs Flame of Gasification process.

\section{Conclusion}

The results of the performance of gasification based on RDF of palm waste at several variations of combustion airflow rate can produce syngas continuously for 3 hours operation. Increased linear flow rate with increasing reactor temperature, syngas product, and flame. This happens because the supply of air inputs is still within the limit of stoichiometry gasification reaction, which is $20 \%-40 \%$ air stoichiometry.

This research was partly subsidized by Grant of Program Kemitraan Masyarakat (PKM) research PNPB Universitas Sebelas Maret 2018. The researchers gratefully acknowledge financial support from the LPPM Universitas Sebelas Maret, Surakarta, Indonesia.

\section{References}

1. C. Luca, "Modeling and optimization of biomass gasification systems," no. May, (2009)

2. R. Alipour Moghadam, S. Yusup, W. Azlina, S. Nehzati, and A. Tavasoli, "Investigation on syngas production via biomass conversion through the integration of pyrolysis and air-steam gasification processes," Energy Convers. Manag., vol. 87, pp. 670-675, (2014)

3. R. A. Moghadam, S. Yusup, Y. Uemura, B. L. F. Chin, H. L. Lam, and A. Al Shoaibi, "Syngas production from palm kernel shell and polyethylene waste blend in fluidized bed catalytic steam cogasification process," Energy, vol. 75, pp. 40-44, (2014)

4. T. M. Ismail and M. A. El-Salam, "Parametric studies on biomass gasification process on updraft gasifier high temperature air gasification," Appl. Therm. Eng., vol. 112, pp. 1460-1473, (2017)

5. T. Golden, B. Reed, and A. Das, Handbook of Biomass Downdraft Gasifier Engine Systems, no. 
March. (1988)

6. Z. S. Liu, C. L. Lin, T. J. Chang, and W. C. Weng, "Waste-gasification efficiency of a two-stage fluidized-bed gasification system," Waste Manag., vol. 48, pp. 250-256, (2016)

7. L. Ding et al., "Development of an ultra-small biomass gasification and power generation system: Part 2. Gasification characteristics of carbonized pellets/briquettes in a pilot-scale updraft fixed bed gasifier," Fuel, vol. 220, no. January, pp. 210-219, (2018)

8. D. T. Pedroso, E. B. Machín, J. L. Silveira, and Y. Nemoto, "Experimental study of bottom feed updraft gasifier," Renew. Energy, vol. 57, pp. 311316, (2013)

9. T. M. Ismail and M. A. El-Salam, "Numerical and experimental studies on updraft gasifier HTAG," Renew. Energy, vol. 78, pp. 484-497, (2015)

10. H. Saputro et al., "The CFD Simulation of Cyclone Separator without and with the Counter-cone in the Gasification Process," IOP Conf. Ser. Mater. Sci. Eng., (2018)

11. L. Wang, C. L. Weller, D. D. Jones, and M. A. Hanna, "Contemporary issues in thermal gasification of biomass and its application to electricity and fuel production," Biomass and Bioenergy, vol. 32, no. 7, pp. 573-581, (2008)

12. A. Saravanakumar, T. M. Haridasan, T. B. Reed, and R. K. Bai, "Experimental investigation and modelling study of long stick wood gasification in a top lit updraft fixed bed gasifier," Fuel, vol. 86, no. 17-18, pp. 2846-2856, (2007)

13. [A. T. Mustafa, "Experimental Study of Air Flow Rate Effect On Humidification Parameters With Preheating And Dehumidification Process Changing," J. Eng. Appl. Sci., vol. 6, no. 9, pp. 63$68,(2011)$ 